\title{
Political Economic Conditions of a Good Life Beyond Growth
}

Andrew Sayer, January 2016. Draft of article to be published in Rosa, H. and Henning, C. (eds) The Good Life Beyond Growth, Routledge, 2018

\section{Introduction}

For over two centuries, it has been widely assumed that economic growth is not just necessary for a good life, but a part of it. One reason for our reluctance to accept that it is neither inevitable nor desirable, at least in the rich countries, is that zero growth in capitalism with crises and hardship, and it is hard to imagine a feasible alternative political economic system that could support a good life beyond growth. In this contribution I suggest what kind of economy might be environmentally sustainable and be fair and conducive to well-being. Our current economy performs badly on the first and second of these criteria, and unevenly on the third. Although there are some obvious regulatory changes to protect the environment and social welfare that might help to meet these criteria, it is argued here that particularly given capitalism's evident dependence on economic growth, and the need to drastically cut emissions of greenhouse gases, deeper changes in economic institutions are also needed.

And since our economy is not simply a technical system but a political economy a vast network of social relations in which a highly unequal distribution of power inheres - we need to make the political challenges clear. As we shall see, in many ways, there is a convergence between traditional left critiques of our dominant economic system - capitalism - and environmental critiques.

The challenge of building a carbon-neutral economy obliges us to go back to basics and reconsider what an economy is for, and consider the nature of the social and material, environmental relations involved. So before discussing some alternative political economic institutions, I will begin with some of these basic issues and argue for a moral economic approach.

\section{Back to basics}

The point of economic activity is simply to enable us to live well. Wealth is not money but whatever supports flourishing. Economies are systems of provisioning - ways of providing us with the wherewithal to live a decent life and of course some systems of provision are much better than others. In capitalism, provisioning is not the prime goal, but a common, though not universal, by-product of the pursuit of profit.

Provisioning involves two kinds of relations:

- relations between people, whether as buyers and sellers, employers and employees, lenders and borrowers, or landlords and tenants, citizens and governments, or as providers and beneficiaries of unpaid work. 
- our relations to the environment, All material wealth ultimately depends on this, so looking after the environment should make economic sense: degrading it does not.

No one ever became rich or poor outside these two sets of relations. 'Moral economy' focuses on these and examines whether they are fair or unfair, functional for provisioning or not, and sustainable or unsustainable (Sayer, 2007; 2014). Particularly at this time of economic and environmental crisis, it can provide us with signposts to a different way of doing things. I shall introduce features of a moral economic approach that deal primarily with the social relations of the economy, before moving on to environmental issues.

Mainstream economics ignores or misunderstands these relations: 'homo oeconomicus' is assumed to be a free-standing, adult man, self-interested and entering only into contractual relations with others where he wishes. But a society comprised wholly of such individuals is an impossibility. We are social beings. This means not merely that we happen to live in groups, but that we are inherently dependent on others: entering into social relations is not only necessary but unavoidable. Most fundamentally this is because we all start off as helpless babies, utterly dependent on our carers. This is a universal. And particularly in old age or illness we again become dependent on others. Dependency can be good (having good parents), or it can be bad, a source of exploitation and domination. It's important to know the difference, but mainstream economic thought ignores the first and largely conceals the second. Both are of primary interest to moral economy,

To recognise the difference we need to notice that there are three ways you can get an income:

First you can produce some goods or services that others want and can pay for. (Something-for-something.) This earned income can come either from selling the goods, or in the case of the public sector, from taxes. This is not to say that the pay reflects the value of what is contributed, merely that getting paid is conditional on making some kind of contribution to the production of goods and services.

Second, if you're not able to produce goods or services or provide for yourself - because you're too young, old or infirm to work, or because there are not enough jobs to go round - others may agree to meet your needs, whether privately or through democratically agreed transfers via the state. The criterion for transfers is generally one of need: the recipients are unable to contribute to provisioning (or do but without getting paid for it), and hence depend on transfers to meet their needs.

Third, you can get money from others by controlling existing assets like property or money that they need but lack, and can therefore be made to pay for. If the assets already exist and have been paid for, then the income is unearned - something-for-nothing. And since the money the owners get only has any value if there are goods and services they can buy with it, then those who produce them must be producing more than they 
themselves can buy with their pay in order to support this free-riding.

This is unearned income based on power, through control of assets.

These three sources are to be found in any modern economy; outside the cash economy their equivalents involve payments received in kind. Whereas the first two are clearly needed in some form, the third is not: as something-for-nothing, it is both unjust and dysfunctional. Earned income is conditional on contributions to wealth creation, where wealth can include non-monetised goods, like education. Asset-based unearned income is based on wealth extraction, on free-riding or exploitation. An alternative economy that is both feasible and fair must be one that blocks or taxes away most of this, and provides transfers and supports earned income, whether funded via markets or taxes.

In thinking about alternative economies as well as already existing ones it's vital to note that what is commonly called 'investment' can involve wealth creation and/or wealth extraction. In the former case, it involves funding and creating things that enhance our possibilities for flourishing - new technologies, infrastructure, training and education, or replacing worn out stuff in order to prevent deterioration. It may yield the investor a return, or it may not. The second sense of 'investment' focuses on the investor and their return, regardless of whether the money they put forward funds the creation of anything new. Returns on savings, rent, capital gains, dividends on shares, and speculative gains need not have any connection to wealth creation; they are forms of wealth extraction. The use of the same word for these two different activities allows the latter to be passed off as the former. The elision contributes to the mystification of contemporary economic life, and legitimises the activities of rich 'investors', most of whose income has little to do with wealth creation.

We can also think about property in more critical ways that complement the above points. Nearly a100 years ago, J.A.Hobson highlighted the difference between property and 'improperty' (Hobson, 1937). ${ }^{1}$ Property includes objects individuals use themselves or with other co-owners, like a home, the equipment and materials they use to make things with, such as cooking equipment, and other possessions. In other words, their point is their use-value to the owner(s). By contrast, where such objects are held not for the owner's own use, but as a means of getting others who lack them to work for the owner for them or pay them rent, they are improperty, and an investment only in the second sense. If you are a self-employed plumber, your equipment is property; you use it to produce useful goods and services. But the owner(s) of a plumbing firm can make it merely a means for getting money by delegating management and still extracting profit without contributing anything themselves in terms of work (or they can get a combination of earned and unearned income by working too). It is not only unjust but dysfunctional since the unearned income provided for the owner is a deadweight cost on the system. Whereas property is limited to what the owner can use or work with, the lack of restriction on how much improperty individuals or institutions may hold and on what they may do with it, means its

\footnotetext{
${ }^{1}$ R.H. Tawney's view that property should be "an aid to work, not an alternative to it" complements this (Tawney, 1920, p.54).
} 
scope for growth is larger than for property, though ultimately the value of money gained thereby depends on the production of goods and services by others which it can buy. Further, since receipts of rent and other forms of unearned income tend to concentrate at the top of the income distribution, they support wasteful and shockingly unsustainable consumption by the rich and super-rich, while revenue they don't consume is recycled into further rentseeking activities (Sayer, 2014).

Wherever, as under capitalism, market competition is coupled with the rule of improperty, and unrestrained by legislation and organized labour, it rides roughshod over the interests of workers and over environmental concerns. Those who produce the goods that provide the owners with profit have little or no say in their organizations' running, and particularly on the disposal of its revenues, so instead of inter-firm competition being regulated by the players or producers, it is dominated by the interests of owners. Under capitalist rules, while one can work for a firm for decades and never have any influence over its running, anyone with enough money to buy the company can step in and do what they like with it, and extract as much income as they wish without any responsibility to others, with fateful consequences. Here the basic social relations are problematic, and constitute a form of ill-being.

Rent, interest, capital gains, and dividends are all forms of unearned income deriving from improperty. The traditional term for recipients of this income is rentier, though of course it's possible for individuals to get both earned and unearned income, and so be part-rentiers. Given that organizations can function as rentiers, those who work for them may get a salary and appear to have earned income, but actually be rentiers at one remove. Capitalist-owned means of production is also improperty, though for capitalists ${ }^{2}$, unlike rentiers, their profit is at least dependent on its use for producing commodities. A viable alternative, advanced economy will need both private and social property (local and national), but it does not need improperty.

\section{A sustainable economy}

Never-ending growth - at least in the rich countries - in a finite world is an absurdity. And yet the growth imperative is a near-universal assumption of mainstream politics and popular thinking on the economy. No wonder then, that the dream of 'green growth' - in which carbon emissions are decoupled from economic growth - should be so appealing. But as Tim Jackson has demonstrated, this is, to say the least, improbable. ${ }^{3}$ Even though the energy and carbon intensities per unit of output have declined, so that the 'energy intensity' of each unit of output is 33\% lower now than in 1970 globally, this has been more than offset by economic and population growth, such that $\mathrm{CO} 2$ from fossil fuels

\footnotetext{
${ }^{2}$ Here I am referring to capitalists in the classic Marxist sense i.e. directly involved in the circuit of capital M - C . . P . . . C' - M', excluding those who make money from money M-M'.

3 However, Jackson considers zero-growth capitalism a possibility under certain circumstances (e.g. Jackson and Victor, 2011).
} 
increased by $80 \%$ from 1970 to 2007 and by 40\% from 1990, growing at 3\% per year between 2000 and 2007 (Jackson, 2009). Since that time, the situation has become still more urgent. Even during the most serious economic recession since the Great Crash of the interwar period, emissions have continued to grow.

As the Pope argued in his encyclical in 2015, inequality and climate change are inextricably linked. If we are to stand a chance of reducing carbon emissions to a sustainable level, then the biggest emitters - the rich countries and especially the rich and well-off within them - need rapidly to cut their emissions. The most straightforward model for this is 'contraction and convergence'. This is based on a simple calculation in which one takes an estimate of the world's capacity for reabsorbing carbon sustainably, and divides it by the world's population to give an individual emissions allowance. There might be qualifications needed to such a policy, but its moral force is clear: those individuals or countries which exceed this and hence are damaging the planet for everyone need to cut back their emissions to this level, while those individuals or countries which emit less than the allowance should be allowed to grow up to it. Of course, this idea horrifies the governments of rich countries, though it lets them off lightly because it is based only on current, not historical emissions, even though green house gases take many decades to be reabsorbed.

Climate scientist Kevin Anderson and colleagues argue that given the long leadtimes involved in substituting low carbon energy sources for fossil fuels, the only way we can avoid 'extremely dangerous climate change' now is by cutting consumption itself in the rich countries. Carbon emissions per head correlate positively with income, and globally, $49 \%$ of consumption-related emissions derive from the richest $10 \%$ of the world's population 4 , so according to the polluter pays principle, it is here that the biggest responsibilities lie. Anderson estimates that a " $30 \%$ reduction in global emissions could be delivered in under a year, simply by constraining the emissions of that $10 \%$ responsible for half of all global CO2 to the level of a typical European." ${ }^{5}$ Given the seriousness of the situation, the need to consider zero growth and actually reduce some activities is inescapable.

Could there be zero-growth capitalism? ${ }^{6}$ Empirically, the association of capitalism with growth is very strong, indeed in a broader historical perspective it's spectacular. Further, in periods when growth has stalled, capitalism has gone into crisis, causing widespread unemployment. Capitalism is not only growthoriented but tends to over-accumulation as each enterprise seeks a dominant position, so productive capacity tends to grow faster than demand, leading to recurrent crises, in which surplus capital is destroyed. There can be no equilibrium or steady-state in which owners merely use profits to cover replacement investment, and consume what's left themselves, abstaining from any innovation or change that might increase their profits. As long as capitalist

\footnotetext{
${ }^{4}$ Source Oxfam, 2014.

${ }^{5}$ Anderson, K. (2015) Duality in climate science http://kevinanderson.info/blog/category/quickcomment/

6 For discussions of this issue, see the debate in Ecological Economics, 2012, particularly Griethuysen's contribution, and also Jackson and Victor, 2011 and Kallis (2015).
} 
investors (in either sense) see opportunities for increasing their returns, they are likely to pursue them, compelling competitors to do so too, or go bankrupt.

On the face of it, increases in labour productivity are the essence of economic development, enabling us to do far more in a given time than our ancestors could. They offer us the chance to reduce working time and enjoy more leisure. But for capitalist firms this is not an option. Labour productivity gains are pursued in order to increase or defend profits in the face of competition, and that means producing more per worker without reducing working hours. This may drive down prices and increase demand and drive growth, but if not, increased labour productivity can lead to downsizing of the work force and forced leisure without pay - i.e. unemployment. Not surprisingly, labour interests within capitalism tend to be pro-growth.

In a steady-state economy, it is therefore important to legislate to reduce labour hours, to inhibit growth while avoiding unemployment, and to improve our work-life balance. At the same time, unless there are restraints on competition from firms in other countries that have longer working hours, such a policy may fail. However, as we shall see competition is likely to reduce anyway in such an economy. In addition, economies can shift resources to lower productivity sectors such as social care. From a capitalist perspective these are unattractive because their low labour productivity makes them unprofitable, but from the point of view of well-being and zero growth, they make perfect sense (Jackson and Victor, 2011).

Labour productivity improvements can also be problematic insofar as saving labour time is prioritized over conserving resources. In many cases reductions in the labour intensity of production have been bought at the expense of increased energy and materials throughput. Thus disposable plastic spoons save us the labour of washing-up, but depend on continued extraction of oil, and the use of more fossil fuel to convert it into plastic and mould it. In a sustainable economy, some sectors will need to be more labour intensive - as we find with organic farming. Undoubtedly, environmentally destructive practices have to be blocked by regulation.

It might seem that the most straightforward way to get a green economy would be not just to regulate it comprehensively plan it centrally, to ensure that this goal was met. But the history of such systems is of course damning. As Frederik Hayek and Alec Nove explained in different ways, the complexity of modern economies, their millions of different products, the intractability of their divisions of labour and the impossibility of centralising the knowledge that is needed for their myriad economic activities, make comprehensive central planning technically infeasible Hayek, 1988; Nove, 1983; Sayer, 1995). ${ }^{7}$ Moreover, the hierarchical organization of the economy required by central planning suppresses local initiative and democratic voice, and supports

\footnotetext{
7 There is a danger that some degrowth supporters, like many socialists before them, underestimate the inevitable complexity of the division of labour required for an advanced economy, and hence underestimate the problems of coordinating provisioning activities without markets.
} 
authoritarian political regimes. So while state ownership and central planning may be best for a few sectors, such as large-scale energy production and distribution, markets - with appropriate regulation to protect labour, health and the environment - would be preferable for coordinating much of the remainder.

But if markets can provide an effective and politically acceptable way of coordinating much of the division of labour, does this not entail capitalism and competition? Not necessarily. Capitalism combines markets with improperty, but markets can also be combined with property, if enterprises are run by those who work for them. In the case of worker-owned co-operatives producing for markets, there would still be competition, though it is likely to take a milder form than under capitalism. Such enterprises are unlikely to accept continually intensified work, or to make themselves redundant in order to transfer production to cheaper, more exploitable labour, or to take a short-term view of strategy. And faced with opportunities for increased labour productivity, cooperatives would have less incentive to pursue growth rather than reduced work time, particularly if they didn't have to compete with capitalist enterprises, and if maximum working hours were regulated nationally, and perhaps internationally (as they are already in many EU countries). Finally, as any shares in them could not be sold and would normally be redeemable only at their original value, their value would not increase if the co-operatives grew, thus making growth less attractive (Johanisova et al, 2015).

While some competition would remain we might also expect it to be reduced and localised as a consequence of the high cost of transport, which would follow from drastic reductions in the supply of fossil fuels on which road, air and seatransport currently rely. The resulting processes of 'de-globalization' would also reduce the reliance of the global north on cheap labour in the global south. Environmentally, this would also mean that carbon emissions would be harder to export to other countries through offshore manufacturing.

All this may mean that some goods and services will be more expensive than they would under a system of unrestrained capitalist competition, but then this will be necessary for protecting workers and the environment. The rate of innovation might slow down too, but it would mean greater economic security and less stressful work, and in any case we must learn to make things that last instead of continually replacing them with newer models.

Particularly in light of its rise to dominance under neoliberalism, we need also to consider the financial sector and its role in a post-growth society. In the last 35 years the financial sector has shifted from servant to master within the economy, so that it now mainly serves itself. Most of its lending is against existing property and improperty, producing asset inflation and a succession of bubbles, transferring income from the asset poor to the asset rich, and with little real investment as a result. Its reckless expansion of debt has been underwritten by the public, allowing it to continue much as before the crash, retaining gains and socialising its costs. These debts can only be paid off by continued growth in the so-called real economy. As it stands, then, the sector could scarcely be more dysfunctional for a green economy. Here it will be necessary to regulate all 
financial products to determine whether they are socially beneficial, in much the same way as new drugs have to be approved before being released onto the market. But it will also be necessary to create publicly-accountable regional, national and sectoral investment banks that undertake real investment in projects that benefit the environment and society. Further, as Mary Mellor argues, the power to create money is of central importance in any economy and society. At present most money $-97 \%$ in the UK - is digital money created as debt by private banks. Democratic control over money creation is vital if we are to shift to a sustainable economy (Mellor, 2015).

A universal basic income has been proposed by some advocates of de-growth (D'Alisa et al, 2015). While this might have many benefits, there are two kinds of objection to it. First, as regards principle, as an unconditional transfer of income from those who worked for money and paid tax, to everyone else (including themselves), it differs from transfers as we have defined them above in that even those perfectly capable of working are freed from any responsibility to do so. Of course, they might do unpaid work such as childcare and eldercare, but then there are arguments for making specific payments via the state for such sociallybeneficial activities. But otherwise, it licences free-riding on others' work, and is therefore questionable from the point of view of economic justice. (Contrary to a common view in both liberal and socialist circles, economic justice is about contribution as well as distribution.) Nevertheless, if it were democratically approved, then that objection would be overruled. ${ }^{8}$ Second, as regards practicality, for democratic decisions on a universal basic income to be adequately informed, realistic estimates would be needed of the amount of paid work that would need to be performed to provide enough to meet the demand it created, and of the level of taxation of workers necessary to fund it. Too often its feasibility is simply assumed. In view of these objections, I suggest that an extension of conditional transfers and full employment policies would be preferable.

While markets are likely to work differently with worker-controlled competition, there would still need to be strong regulation of markets, and a raft of other policies including maximum as well as minimum pay limits, protection and enlargement of carbon sinks. Some products and services could still be decommodified, as called for by many supporters of degrowth (D'Alisa et al, 2015), and increased support for those currently providing important services particularly care work - unpaid.

These proposals would redistribute income and power to the lower half of the income distribution, at the expense of those of those with incomes above the well-being threshold. In a world where the richest 62 people have as much wealth as the poorer half of the world's population, all 3.6 billion of them (Oxfam, 2016), it would be naïve to think this concentration of economic power was not coupled with an extraordinary concentration of political power. At base, this

\footnotetext{
${ }^{8}$ As regards well-being, being able to work and contribute to society is an important component of flourishing; again, the work might be voluntary rather than paid, but in either case it is something which should be encouraged, not devalued.
} 
power derives simply from big corporations' control of the commanding heights of the economy and of much of the media, but it is heavily backed up by political funding, lobbying, and influence over political change and the rules of economic engagement (for example, as in trade treaties like the Transatlantic Trade and Investment Partnership). It is clear that a good life beyond growth will only be attainable through counter forces strong enough to challenge and remove their political power. Legislation will be needed to change capitalist property relations, and to block or tax away unearned income deriving from control of improperty. In the case of our current fossil-fuel dependent energy companies, their size and political clout is such that the only way to wean them off fossil fuel sources quickly enough to stop runaway global warming is to nationalise them and force them to change.

\section{Conclusions}

"Green is the new red", warned Nigel Lawson, former UK Conservative Chancellor and prominent climate change sceptic. He was partly right. At both international and intranational scales there are synergies between movements for social and economic justice and for a sustainable economy, though much of the left has still to face up to the implications of runaway global warming.

There are some obvious preconditions for a good life beyond growth, most obviously massive investment in renewable energy and low-carbon production. But the idea that capitalism can be steered in a zero-growth direction simply by appropriate policy carrots and sticks - such as carbon taxes and clean energy subsidies - overlooks its most destructive feature - its growth imperative, and its associated concentration of economic and political power. In evaluating possible alternatives, a moral economic approach that assesses the fairness of basic economic relations and our unequal impact on the environment, has much to offer.

\section{References}

Anderson, K. (2015) 'Duality in climate science.' http://kevinanderson.info/blog/category/quick-comment/

Blauwhof, F.B. (2012) 'Overcoming accumulation: Is a capitalist steady-state economy possible?' Ecological Economics 84, 254-261.

D’Alisa, G., Demaria, F. and Kallis, G. (eds.)(2015) Degrowth: A Vocabulary for a New Era, London: Routledge.

Griethuysen, Pascal van (2012) 'Bona diagnosis, bona curatio: How property economics clarifies the degrowth debate' Ecological Economics, 84 262-269. Hayek, F.A. (1988) The Fatal Conceit: the Errors of Socialism, London: Routledge. Hobson, J.A. (1937) Property and Improperty, London: Gollancz. Jackson, T. (2009) Prosperity without Growth, Earthscan. 
Jackson, T. and Victor, P. ( 2011) 'Productivity and work in the 'green economy': Some theoretical reflections and empirical tests', Environmental Innovation and Societal Transitions 1, 101-108.

Johanisova, N., Padilla, R.S. and Parry, P. (2015) 'Co-operatives' in D’Alisa, G., Demaria, F. and Kallis, G. (eds.) Degrowth: A Vocabulary for a New Era, London: Routledge, 152-5.

Kallis, G. (2015) 'Is there a growth imperative in capitalism?'

http://entitleblog.org/2015/10/27/is-there-a-growth-imperative-in-capitalisma-response-to-john-bellamy-foster-part-i/

Mellor, M. (2015) Debt or Democracy, Chicago, Illinois: Chicago University Press. Nove, A. (1983) The Economics of Feasible Socialism, London: Allen and Unwin Pope Francis (2015) 'Encyclical letter Laudato Si' of the Holy Father Francis on care for our common home.' http://liberationtheology.org/pope-

francissencyclical-on-ecology-june-2015

Sayer, A. (1995) Radical Political Economy: A Critique, Oxford: Blackwell.

Sayer, A. (2007) 'Moral economy as critique', New Political Economy, 12 (2), pp.261-270.

Sayer, A. (2014) Why We Can't Afford the Rich, Bristol: Policy Press.

Tawney, R.H. (1920 [2004]) The Acquisitive Society, Mineoloa, NY: Harcourt, Brace and Howe. 